\title{
The Role of Corporate Social Responsibility as a Moderator on the Effect of Profitability and Company Size on Tax Aggressiveness
}

\author{
Rr. TjahjaningPoerwati \\ Departement of Accounting, Universitas Stikubank \\ Semarang, Indonesia \\ tjahjaning.poerwati@edu.unisbank.ac.id \\ Nur Aini \\ Departement of Accounting, Universitas Stikubank \\ Semarang, Indonesia \\ nuraini@edu.unisbank.ac.id
}

\author{
Maryono \\ Departement of Accounting, Universitas Stikubank \\ Semarang, Indonesia \\ maryono@edu.unisbank.ac.id \\ TeguhParmonoHadi \\ Departement of Accounting, Universitas Stikubank \\ Semarang, Indonesia \\ teguh@edu.unisbank.ac.id
}

\begin{abstract}
This study was conducted to analyze the effect of profitability and company size on tax aggressiveness with Corporate Social Responsibility as a moderating variable. The population of this research is manufacturing companies listed on the Indonesian Stock Exchange in 2014-2017 with a sample proposive sampling method, obtained data from 179 companies. The data analysis technique used Moderated Regression Analysis (MRA). The results of this study indicate that profitability and company size have a significant negative effect on tax aggressiveness, while Corporate Social Responsibility is able to strengthen profitability and weaken company size against tax aggressiveness.
\end{abstract}

Keywords: Profitability, Company Size, Corporate Social Responsibility, Tax Aggressiveness

\section{INTRODUCTION}

Sources of state revenue come from various sectors, both internal and external. One source of state revenue from the internal sector is taxes, while external sources of revenue are for example foreign loans. For Indonesia, state revenues derived from taxes are still the largest revenue for the State Budget (APBN). Taxes have alwaysbeenthefocusofthe government because taxes are the biggest focus in the State Budget (APBN).

Tax is the people's contribution to the state treasury based on law (which can be enforced) without receiving reciprocal services (counter-achievement) which can be shown directly and which is used to pay

The second factor that affects tax aggressiveness is the size of the company. According to research conducted by [13],[6], [24] company size has a significant positive effect on tax aggressiveness, whereas according to [15] and [17] company size does not have influence on tax aggressiveness.

The third is Corporate Social Responsibility (CSR). According to The Word Business Councill For Sustainable Development (WBCSD) or what is currently called business action for sustainable development, quoted general expenses. The accounting sector states that tax is a cost component which can reduce company profits. The amount of tax that must be deposited to the state treasury depending on the amount of profit the company gets during one year. Paying taxes in accordance with the provisions will of course contradict the main objective of the company, namely maximizing profits or profits, so that the company tries to minimize the tax costs it bears[3]. The methods used by the company include tax planning or tax aggressiveness. Corporate tax aggressiveness is also assessed by the extent to which the company takes tax avoidance measures by exploiting loopholes in tax regulations. So by doing so, the company will be considered more aggressive towards taxation. There are several factors that influence companies in implementing tax aggressiveness, including profitability, Company Size, and Corporate Social Responsibility.

Low profitability may reflect that the company has difficulty meeting short-term obligations [9]. Liquidity difficulties can trigger companies to disobey tax regulations [20] so that they can lead to aggressive actions against corporate taxes. According to research conducted by [6] and[1] profitability has a significant positive effect and according to [21] and [18] profitability has a significant negative effect on tax aggressiveness. Meanwhile, according to research conducted by [15] profitability has no influence on tax aggressiveness.

from [22]defines CSR as a sustainable commitment from business people to behave ethically and contribute to economic development while at the same time improving the quality of life of workers and their families as well as local communities and the wider community.Research conducted by [26] has shown that the higher the level of disclosure of Corporate Social Responsibility (CSR), the lower the aggressiveness of the company. According to research conducted by [12] and [15] CSR has a significant positive effect on tax aggressiveness. Meanwhile, 
according to the results of research conducted by [13]revealed that Corporate Social Responsibility (CSR) has a significant negative effect on tax aggressiveness. The inconsistent research results can encourage to conduct further research on the influence of variables on tax aggressiveness.

\section{LITERATURE REVIEW}

\section{Agency Theory}

Agency theory explains the relationship between the principal and the agent[16]. States that in agency or agency theory, there is a contract or agreement between the resource owner and the manager to manage the company and achieve the company's main goal, namely maximizing the profits to be obtained, thus allowing managers to do various ways to achieve these goals in good ways or a way that is detrimental to many parties[12]. The manager (agent) has an obligation to provide information about the company to the company owner (principle) because managers are considered to better understand and know the real condition of the company [3].

\section{Legitimacy Theory}

Legitimacy theory is one of the most frequently mentioned theories in the field of social and environmental accounting. State that legitimacy theory has been used in accounting studies to develop a theory of social and environmental responsibility disclosure. Companies are increasingly aware that the company's survival also depends on the company's relationship with the community and the environment in which the company operates. This is in line with the legitimacy theory which states that companies have contracts with the public to carry out their activities based on the values of justice, and how companies respond to various interest groups to legitimize company actions. Legitimacy theory states that organizations must continually try to ensure that they carry out activities in accordance with the boundaries and norms of society (Rustiarini, 2011) in[27]. Legitimacy Theory states that companies will have a bigger responsibility than small companies (Cheers, 2011) in[27].

\section{Tax Aggressiveness}

Companies consider taxes as an additional expense that can reduce corporate profits. Therefore the company is predicted to take actions that will reduce the company's tax burden. According to[7], actions taken by companies to reduce taxable income through tax planning, both legally (tax avoidance) and illegally (tax evasion) are called corporate tax aggressiveness. Although not all tax planning acts violate the law, the more loopholes are used, the more aggressive the company is.

\section{RESEARCH RESULT}

\section{Effect of Profitability on Tax Aggressiveness}

The results show that profitability has a significant negative effect on tax aggressiveness. Based on the test results, then $\mathrm{H} 1$ = profitability has a significant positive effect on tax aggressiveness" is rejected.

This shows that companies that have high levels of profit actually have a low tax burden. This can be affected by income which should not be included as a tax object but rather as a tax object. The results of this study are supported by [5]who argue that companies with high profitability have the opportunity to position themselves in tax planning which reduces the amount of tax liability.

Companies can reduce the amount of their tax burden by taking advantage of the $\mathrm{PPh}$ article 4 paragraph 3 on non-taxable objects by selecting or generating nontaxable income. For example a PT can invest in a company or business entity in Indonesia, and dividends received by a PT will be categorized as income which is not subject to tax on the condition that the PT has shares of at least $25 \%$ of the total paid-up capital in the company as regulated in the LawIncome Tax Article 4 paragraph 3. The results of this study are in line with the hypothesis conducted by [11] and[10].

2. The Effect of Company Size on Tax Aggressiveness The results show that size has a significant negative effect on tax aggressiveness. Based on the test results, "H2 = size has a significant positive effect on tax aggressiveness" is rejected.

The size of the company can be interpreted as a scale in which the company can be classified as large and small according to various ways, one of which is the size of its assets. The size of the company can determine the size of the assets owned by the company, the greater the assets owned, the greater the amount of productivity. Assets owned by a company are related to the size of the company, large companies tend to have large assets. Assets will experience depreciation each year which can reduce the company's net income, thereby reducing the tax burden paid. The high profit that the company receives will result in higher taxes that must be issued by the company. This condition makes managers try to minimize reported taxes but by reporting high profits, one of which is by diverting them into withheld tax. This condition can cause the total tax burden to be smaller.

There is a significant negative effect of firm size on ETR because large companies have more room for good tax planning and adopt effective accounting practices to reduce company tax aggresiveness. The results of this study are consistent with research conducted by[11] and [27]which states that the larger the company, the relatively lower the effective tax rate is.

3. The Effect of Corporate Social Responsibility Strengthens Profitability on Tax Aggressiveness

Based on the results show that CSR_Profitability has a significant positive effect on Tax Aggressiveness, then H3 = Corporate Social Responsibility strengthens Profitability on Tax Aggressiveness is accepted.

Corporate Social Responsibility strengthens the influence of Profitability on Tax Aggressiveness. Research conducted by[4]states that companies in Indonesia have begun to consider the importance of the existence of corporate social responsibility, so that the greater the benefits obtained, the higher the value of the performance of corporate social responsibility. Corporate social responsibility can also be used by companies to be superior to competitors in terms of getting benefits. Once a company in an industry has successfully implemented a 
corporate social responsibility policy, a competing company may be forced to engage in corporate social responsibility activities as well.

The company in running its business has the aim of obtaining maximum profit / profit. However, companies also have an obligation to pay taxes. The tax burden paid by the company will have an impact on reducing company profits. To maintain or optimize company profits, efforts to minimize the tax burden are carried out through tax avoidance practices. According to Watson (2014) in [1], it is found that companies with good quality corporate social responsibility do not evade tax in conditions of high profit performance, moreover there will be accountability reports that will make the company more transparent. Likewise, according to research conducted by [2] there is an influence between profitability and corporate social responsibility on tax avoidance.

\section{The Influence of Corporate Social Responsibility Weakness The Influence of Company Size on Tax Aggressiveness}

Based on the results show that CSR_SIZE has a significant negative effect on tax aggressiveness, so H4 = Corporate Social Responsibility weakens the size of the company to tax aggressiveness" is accepted.

Companies are classified as small or large from one of them from the small amount of the company's total sales. Benchmarks used to show the size of a company, including total sales, number of regular customers and total assets [27]. The greater the total sales or assets, the bigger the size of a company [17]. Corporate Social Responsibility activities are a manifestation of the company's concern for the community, apart from paying taxes correctly and properly. Corporate social responsibility is a form of communication relationship. This is done so that the company has a positive image in the eyes of stakeholders and the wider community.

In line with the theory of legitimacy, besides obtaining maximum profit, companies are required to pay attention to the community. Company size can be affected by tax aggressiveness. However, when other factors occur, such as the existence of Corporate Social Responsibility, it will weaken the relationship between company size and tax aggressiveness. With good Corporate Social Responsibility, it will strengthen the value of tax aggresiveness, whichmeansthat the company will be more transparent in building good relationships with the community or stakeholders [23].

\section{CONCLUSION}

The results of the analysis of this study state that profitability and firm size have a significant negative effect on tax aggressiveness, while for the moderating variable, Corporate Social Responsibility strengthens profitability and weakens firm size on tax aggressiveness.

\section{LIMITATIONS}

The following are some of the limitations in the study, namely the difference in assessment in analyzing and identifying Corporate Social Responsibility (CSR) disclosure items in annual reports that are subjective, so that they are only based on the author's knowledge. The $\mathrm{R}$ square value of this study is relatively small, namely 0.072 , meaning that the variables in this study only affect $7.2 \%$ and the remaining $92.8 \%$ are influenced by other variables outside the research and the research unit is only companies engaged in the manufacturing industry.

\section{SUGGESTION}

For the next researcher, it is hoped that they can increase the number of other independent variables that affect company aggressiveness, such as: Leverage and Earnings Management and add observations, in this study it was only 4 years (2014-2017) and not only researched in manufacturing companies but also in other companies, such as banking.

\section{REFERENCES}

[1] Amalia Sari, Nur. 2018. Pengaruh Profitabilitas dan Leverageterhadap Penghindaran Pajak dengan Pengungkapan Corporate Social Responsibility (CSR) sebagai Variabel Pemoderasi. Skripsi Fakultas Ekonomi Universitas Islam Negeri (UIN), Malang.

[2] Agusti, Wirna Yola. 2014. Pengaruh Profitabilitas, Leverage, Corporate Governance Terhadap Tax Avoidance. ArtikelIlmiah. Program StudiAkuntansi Fakultas EkonomiUniversitas Negeri Padang.

[3] Ardyansyah, Danis. 2014. Pengaruh Size, Leverage, Profitability, Capital Intensity Ratio dan Komisaris Independen terhadap Effective Tax Rate (ETR). Fakultas Ekonomika dan Bisnis Universitas Diponegoro, Semarang.

[4] Badjuri, Achmad. 2011. Faktor-faktor Fundamental, Mekanisme Corporate Governance, Pengungkapan Corporate Social Responsibility (CSR) Perusahaan Manufaktur dan Sumber Daya Alam di Indonesia.Dinamika Keuangan dan Perbankan. Journal of Accounting, Vol.3 No. 2 Hal: 183-197. Universitas Stikubank,Semarang.

[5] Chen, K. P, dan Chu, C. Y. C. 2010. Internal Control vs External Manipulation: A Model of Corporate Income Tax Evasion.Rand Journal of Economics

[6] Devi, Dewa Ayu dan Luh Gede. 2019. Pengaruh Profitabilitas pada Agresivitas Pajak dengan Pengungkapan Corporate Social Responsibility (CSR) sebagai Variabel Moderasi. Fakultas Ekonomi dan BisnisUniversitas Udayana, Bali.

[7] Frank, M., Lynch, L., dan Rego, S. (2009). "Tax Reporting Aggressiveness and Its Relation to Aggressive Financial Reporting". The Accounting Review, vol. 84, hal.467-496.

[8] Gemilang, Dewi Nawang. 2017. Pengaruh Likuiditas, Leverage, Profitabilitas, Ukuran Perusahaan dan Capital Intensity terhadap Agresivitas Pajak Perusahaan (Studi Empiris pada Perusahaan Property dan Real Estate yangTerdaftar di BEI 2013-2015). Skripsi Fakultas Ekonomi dan Bisnis Islam Institute Agama Islam Negeri, Surakarta.

[9] Krisnata, D.S, 2012. Likuiditas, Leverage, Manajemen laba, Komisaris Independenterhadap Agresivitas Pajak Perusahaan.Jurnal Keuangan dan Perbankan, Vol.16, No.2, hlm. 167-177.

[10] Kurniasih, Tommy dan Maria M.Ratna Sari. (2013) "Pengaruh Return on Assets, Leverage, Corporate Governance, Ukuran Perusahaan Dan Kompensasi Rugi Fiskal Pada Tax Avoidance".Buletin Studi Ekonomi. (18). hal. 58-66

[11] Lanis, R., and Richardson, G.2012. Corporate Social Responsibility and Tax Aggressiveness: An Empirical Analysis. Journal of Accounting and Public Policy, 3(1),86-108. https://doi.org/10.1016/j.jaccpubpol.2011.10.006.

[12] Luayyi, Sri. 2010. Jurnal "Teori Keagenan dan Manajemen Laba dari Sudut Pandang Etika Manajer”, Universitas Brawijaya, Malang.

[13] Luke, Zulaikha. 2016. Analisis Faktor yang Mempengaruhi Agresivitas Pajak (Studi Kasus pada Perusahaan Manufaktur 
yang Terdaftar di BEI 2012-2014). Jurnal: Universitas Diponegoro, Semarang.

[14] Mulianti, Fitri Mega. 2010. Analisis Faktor-Faktor yang Mempengaruhi Kebijakan Hutang dan Pengaruhnya terhadap Nilai Perusahaan (Studi Pada Perusahaan Manufaktur yang Terdaftar di Bursa Efek Indonesia (BEI) Periode Tahun 20042007), Tesis Program Studi Magister Manajemen, Universitas Diponegoro, Semarang.

[15] Mustika.2017. Pengaruh Corporate Social Responsibility, Ukuran Perusahaan,Profitabilitas, Leverage, Capital Intensity dan Kepemilikan Keluarga terhadap Agresivitas Pajak (Studi Empiris pada Perusahaan Pertambangan dan Pertanian yang Terdaftar di Bursa Efek Indonesia Periode Tahun 2012-2014). Faculty of Economic Riau University, Pekanbaru, Indonesia.

[16] Nugraha, N. B., danMeiranto, W. (2015). Pengaruh Corporate Social Responsibility, Ukuran Perusahaan, Profitabilitas, Leverage dan Capital Intensity terhadap Agresivitas Pajak (Studi Empiris Pada Perusahaan Non Keuangan yang Terdaftar di BEI Tahun 2012-2013). Diponegoro Journal of Accounting. 4 (4), 1 14

[17] Pande Putu, dan Ni Ketut. 2019. Pengaruh Ukuran Perusahaan, Profitabilitas Koneksi Politik dan Pengungkapan Corporate Social Responsibility pada Tax Avoidance. Universitas Udayana, Bali.

[18] Pamor, Dani Yani.2017.Pengaruh Likuiditas, Profitabilitas, Intensitas Persediaan dan Ukuran Perusahaan terhadap Tingkat Agresivitas Wajib Pajak Badanpada Perusahaan Manufaktur yang Terdaftar di BEI Tahun 2012-2016. Universitas Maritim Raja Ali Haji, Riau.

[19] Prameswari, Findria. 2017. Pengaruh Ukuran Perusahaan terhadap Agresivitas Pajak dengan Corporate Social Responsibility (CSR) sebagai Variabel Moderasi. Universitas Negeri Surabaya. Jurnal Ekonomi Akuntansi Vol.3 Issue 4.
[20] Putri, Lucy Tania Yolanda. 2014. Pengaruh Likuiditas, Manajemen Laba dan Corporate Governance terhadap Agresivitas Pajak Perusahaan (Studi Empiris pada Perusahaan yang Terdaftar di BEI Periode 2008-2012. Fakultas Ekonomi, Universitas Negeri Padang. Diakses 24 Juli 2017 dari www.unp.ac.id.

[21] Ramila, Prima Aprilyani, dan Sri Ruwanti. 2017.Pengaruh Corporate Social Responsibility, Profitabilitas, Leverage dan Capital Intensity terhadap Agresivitas Pajak pada Perusahaan Manufaktur yang Terdaftar di Bursa Efek Indonesia Tahun 2013-2016. Universitas Maritim Raja Ali Haji,Riau.

[22] Richardson, Grant and R. Lanis. 2007. "Determinants of Variability In Corporate Effective Tax Rates and Tax Reform: Evidence From Australia". Jorunal of Accounting and Public Policy 26 (2007) 689-704.

[23] Rodriguez, E., F. And Arias, A., M. 2013. "Do Business Characteristics Determine an Effective Tax Rate?". The Chinese Economy, Vol. 45 No. 6.

[24] Solihin, Ismail (2009), Corporate Social Responsibility from Charity to Sustainability, Salemba Empat, Jakarta.

[25] Sunarto dan Budi, A. P. (2009). Pengaruh Leverage, Ukuran dan Pertumbuhan Perusahaan Terhadap Profitabilitas. Jurnal Ilmiah Telaah Manajemen, 6(1), 86-103.

[26] Tiaras, Irvan dan Henryanto Wijaya. 2015. Pengaruh Likuiditas, Leverage, Manajemen Laba, Komisaris Independen dan Ukuran Perusahaan terhadap Agresivitas Pajak.JOM FEB, Vol. 1, Edisi 1 ..

[27] Yoehana, Maretta. 2013. Analisis Pengaruh Corporate Social Responsibilityterhadap Agresivitas Pajak (Studi Empirispada Perusahaan Manufaktur yang Terdaftar dalam BEI 2010-2011). Skripsi Fakultas Ekonomi dan Bisnis Universitas Diponegoro, Semarang. 